\begin{tabular}{lc} 
Jurnal Fokus Manajemen Bisnis \\
Universitas \\
$\begin{array}{l}\text { Ahmad Dahlan } \\
\text { holtps://doi.org/10.12928/ /fokus.v11i2.4228 } \\
\text { http://journal2.uad.ac.id/index.php/fokus }\end{array}$ \\
\hline
\end{tabular}

\title{
PENGARUH INVESTMENT OPPORTUNITY SET, CORPORATE SOCIAL RESPONSIBILITY, DAN RISIKO BISNIS TERHADAP NILAI PERUSAHAAN
}

\author{
Muhammad Fuad Alamsyah ${ }^{1,}$, Widyawati Malanua ${ }^{2}$ \\ Universitas Ichsan Gorontalo \\ Fuadalamsyah@unisan.ac.id \\ *Correspondent Author
}

\section{ARTICLE INFO}

Article History

Received 2021-06-14

Revised 2021-06-21

Accepted 2021-07-28

\section{Keywords}

Investment Opportunity Set

Corporate Social Responsibility

Business Risk

Firm Value

\section{ABSTRACT}

This study aims to determine the effect of investment opportunity set, corporate social responsibility and business risk on firm value. Investment opportunity set is measured using market book value equity, capital expenditure to book value of assets, and corporate social responsibility is measured by corporate social responsibility disclosure index and business risk is measured by business risk in banking sub-sector companies listed on the Indonesia Stock Exchange (IDX) in 2015-2019. The method of determining the sample using purposive sampling then obtained a sample of 39 companies. The data analysis technique used is multiple regression analysis. The results showed that the investment opportunity set consisting of market book value equity had a significant effect on firm value, capital expenditure to book value of assets had no significant effect on firm value, corporate social responsibility had a significant effect on firm value, and business risk had no significant effect on firm value.

This is an open-access article under the CC-BY-SA license.

\section{Pendahuluan}

Persaingan di dunia usaha telah meningkat dengan begitu cepat karena adanya perkembangan dibidang teknologi informasi yang mengakibatkan perubahan pada strategi perusahaan. Setiap perusahaan harus mampu beradaptasi untuk mengikuti perkembangan ekonomi agar dapat bersaing dengan perusahaan lain sehingga dapat mempertahankan perusahaan dan mencapai tujuan perusahaan yaitu meningkatkan tingkat pendapatan pemegang saham (Tan, 2018). Nilai saham dapat digunakan untuk mengukur nilai perusahaan (Wardah, 2019).

Nilai perusahaan merupakan persepsi investor tentang tingkat kekayaan pada pemegang saham. Nilai perusahaan selalu dikaitkan dengan harga saham (Wardah, 2019). Secara umum nilai perusahaan tercermin pada nilai pasar atau harga saham suatu perusahaan yang sudah ditentukan dari permintaan dan penawaran saham oleh pasar saham. Pengukuran dalam nilai perusahaan menggunakan Price Book Value (PBV). PBV adalah perbandingan antara harga saham dengan nilai buku dari perusahaan (Wardah, 2019).

Nilai perusahaan dibentuk dari beberapa variabel nilai pasar saham yang sangat dipengaruhi oleh Invesment Opportunity Set (IOS). Setiap perusahaan memiliki kesempatan investasi dan pemanfaatan kesempatan investasi yang tepat dapat meningkatkan perkembangan perusahaan (Saputri, 2019). IOS merupakan peluang investasi yang nilainya 
tergantung dengan pengeluaran yang sudah ditetapkan manajemen pada waktu yang akan datang, dan juga merupakan investasi yang diharapkan untuk mendapatkan return yang besar (Saputri, 2019).

IOS berhubungan dengan keputusan investasi perusahaan terhadap pihak internal dan eksternal (Rini \& Mimba, 2019). Rencana pada pengeluaran manajemen di masa depan dan pengeluaran di masa sekarang diharapkan dapat memiliki pengembalian yang lebih tinggi dari modal yang sudah dikeluarkan oleh manajemen (Rini \& Mimba, 2019). Penelitian yang dilakukan oleh Hamidah \& Umdiana (2017) menyatakan bahwa adanya pengaruh positif dari IOS terhadap nilai saham perusahaan. Dari hasil penelitian ini memiliki arti bahwa pertambahan kekayaan atau aset pada perusahaan cenderung terjadi pada perusahaan yang banyak melakukan investasi.

Secara umum IOS merupakan biaya pengeluaran yang ditentukan oleh manajemen di masa yang akan datang, yang diharapkan dapat menghasilkan return yang lebih besar. Dalam teori sinyal menjelaskan bahwa pengeluaran pada modal perusahaan merupakan sesuatu yang penting dalam meningkatkan nilai perusahaan, karena semua macam jenis investasi yang dilakukan perusahaan akan memberikan sinyal positif terhadap pertumbuhan dan pendapatan perusahaan yang berdampak pada meningkatnya harga saham dimana harga saham adalah indikator dari nilai perusahaan (Putri \& Setiawan, 2019).

IOS diukur menggunakan 2 jenis proksi utama yaitu IOS berdasarkan harga dan IOS berdasarkan investasi (Putri \& Setiawan, 2019). IOS berdasarkan harga diproksikan dengan Market to Book Value of Equity (MBVE), sedangkan IOS berdasarkan investasi diproksikan dengan rasio Capital Expenditure to Book Value Assets (CA/BVA). Penelitian Sudiani \& Darmayanti (2018) membuktikan bahwa IOS memiliki pengaruh positif signifikan pada nilai perusahaan. Penelitian ini juga dilakukan oleh Giriati (2016) menyatakan bahwa IOS berpengaruh positif terhadap nilai perusahaan, yang artinya apabila IOS menghasilkan peningkatan, maka nilai perusahaan akan semakin meningkat. Oleh karena itu, dengan meningkatnya kegiatan investasi yang dilakukan, maka akan meningkatkam nilai perusahaan.

Salah satu cara untuk meningkatkan nilai perusahaan adalah melalui penerapan Corporate Social Responbility (CSR) merupakan aspek yang paling penting. Dalam sebuah perusahaan hendaknya tidak hanya memperhatikan tanggung jawab situasi keuangan, tetapi juga kondisi sosial dan lingkungan. Hal ini dikarenakan kondisi keuangan yang belum cukup untuk memastikan keberlangsungan pembangunan perusahaan (Wardah, 2019). CSR merupakan media komunikasi antara perusahaan dengan masyarakat tentang kegiatan perusahaan dan tanggung jawab sosial perusahaan. Pengungkapan CSR diukur oleh Agen I. Pengungkapan perusahaan meliputi tiga pengungkapan utama yaitu ekonomi, lingkungan, dan masyarakat sebagai dasar pelaporan keberlanjutan (Wardah, 2019).

CSR dapat mempengaruhi nilai perusahaan. Berdasarkan hasil dari teori stakeholders dan pengungkapan ini dapat berdampak positif terhadap nilai perusahaan (Li, 2017). Bentuk tanggung jawab kepada ekonomi perusahaan, lingkungan, dan karyawan sekitar merupakan suatu aktivitas utama dari CSR, tanggung jawab perusahaan terhadap karyawan diwujudkan dengan meningkatkan kualitas hidup karyawan perusahaan, tanggung jawab perusahaan untuk lingkungan dapat diwujudkan salah satunya juga dengan meningkatkan kualitas hidup dari masyarakat sekitar perusahaan tersebut saat bekerja. Penelitian yang dilakukan oleh Bella \& Suaryana (2017) menunjukkan pengaruh positif antara CSR terhadap nilai perusahaan. Hal ini berarti semakin baik penerapan CSR oleh perusahaan, maka nilai perusahaan akan semakin meningkat.

Aktivitas CSR dianggap sebagai investasi oleh perusahan dan bukan sebagai biaya-biaya sosial. Hal ini karena perusahaan melihat penerapan CSR semakin penting bagi perusahaan (Fajriana \& Priantinah, 2016). Penerapan CSR juga diharapkan bisa menjadi upaya untuk dapat mengurangi risiko, khususnya pada risiko bisnis yang berasal dari dalam perusahaan. Risiko bisnis dapat mempengaruhi reputasi perusahaan dilihat dari harga saham dan minat 
masyarakat terhadap produk atau jasa yang ditawarkan. Risiko juga dapat diartikan sebagai bentuk kondisi ketidakpastian pada keadaan yang akan terjadi nantinya dengan keputusan yang akan diambil saat ini. Ketidakpastian dan risiko adalah dua istilah dasar untuk setiap pengambilan keputusan, kondisi ketidakpastian di masa yang akan datang dapat menimbulkan risiko. Biasanya risiko yang timbul seperti akibat dari perusahaan yang tidak bisa mengontrol biaya operasionalnya sehingga setiap perusahaan harus menentukan keputusan untuk kebutuhan modal bagi perusahaan yang ingin lebih memajukan usaha. Risiko bisnis merupakan ketidakpastian proyeksi dalam pengembalian aktiva di masa mendatang (Fajriana \& Priantinah, 2016).

Risiko bisnis dapat mempengaruhi nilai perusahaan. Menurut penelitian Ratri \& Christianti (2017) setiap keputusan yang diambil perusahaan pasti akan berpengaruh pada risiko bisnis, sehingga dapat mempengaruhi nilai perusahaan. Sesuai dengan teori trade off yang menyatakan bahwa semakin besar hutang, maka semakin besar pula risiko yang akan ditanggung oleh perusahaan sehingga menyebabkan nilai perusahaan menurun. Hal ini dikarenakan biaya bunga tetap yang harus dibayarkan akan meningkatkan risiko dan pendapatan yang diperoleh akan berkurang (Anggraeni dkk, 2018).

Risiko bisnis pada penelitian ini diproksikan dengan EBIT (Earning Before Interest and Tax). Penelitian yang dilakukan oleh Wiagustini \& Pertamawati (2015) dan Dewi (2019) menunjukkan bahwa risiko bisnis berdampak negatif terhadap nilai perusahaan. Artinya, semakin meningkat risiko bisnis perusahaan, maka nilai perusahaan akan semakin menurun. Penelitian ini dilakukan pada sub sektor perbankan disebabkan karena sub sektor perbankan merupakan salah satu sektor yang memiliki peluang yang cukup cerah untuk di masa yang akan datang. Pada kondisi saat ini salah satu sektor yang mendapatkan perhatian yang lebih mendalam sebagai lokasi penanaman modal yaitu pada perusahaan yang bergerak pada sektor perbankan. Hal ini dibuktikan dari nilai total saham sektor perbankan menjadi nilai terbesar diantara sektor lainnya dengan nilai saham Rp 458,57 (Bursa Efek Indonesia, 2019). Dari hasil data yang dikeluarkan oleh Bursa Efek Indonesia tahun 2019, saham pada sub sektor perbankan tumbuh paling tinggi secara sektoral dan mengalahkan sembilan sektor lainnya. Lebih lanjut, perekonomian suatu negara selalu berkaitan erat dengan sektor keuangan, karena sektor keuangan mempunyai pengaruh terhadap pertumbuhan ekonomi negara.

Perusahaan sub sektor perbankan yang terdaftar di Bursa Efek Indonesia (BEI) terdiri dari 45 perusahaan yang berdasarkan data terbaru, namun hanya 39 perusahaan pada sub sektor perbankan yang listing sebelum tahun 2015-2019 dan memiliki laporan keuangan yang lengkap. Perusahaan yang memiliki tingkat pertumbuhan yang rendah dapat menyebabkan risiko bisnis yang tinggi (Saraswathi dkk, 2016). Jika perusahaan memiliki risiko bisnis yang tinggi maka nilai perusahaan akan turun dimata investor, sehingga kemungkinan aset perusahaan akan dijual untuk melunasi hutang yang jumlahnya besar dibandingkan untuk mengembalikan nilai saham yang sudah ditanamkan oleh investor.

\section{Review Literatur dan Hipotesis}

\subsection{Landasan Teori}

\subsubsection{Investment Opportunity Set (IOS)}

Menurut Hakim \& Abbas (2019) IOS atau set kesempatan investasi digunakan sebagai dasar untuk menentukan klasifikasi pertumbuhan perusahaan di masa depan. Besar kecilnya set kesempatan investasi tergantung pada pengeluaran yang diputuskan oleh manajemen dimasa depan. Pada saat ini, pilihan investasi dapat diharapkan, dan pengembalian yang dihasilkan akan lebih besar daripada biaya ekuitas (cost of equity), dan dapat menghasilkan keuntungan (Sanda, 2018).

IOS menggambarkan luasnya peluang investasi bagi suatu perusahaan, namun IOS sangat tergantung pada pengeluaran perusahaan di masa yang datang. Pilihan 
investasi merupakan suatu kesempatan untuk berkembang. Apabila dilihat dari teori sinyal terjadinya pengeluaran untuk investasi oleh perusahaan akan memberikan sinyal yang baik tentang pertumbuhan perusahaan di masa yang akan datang. Hal ini disebabkan oleh persepsi dari para pasar modal yang melihat bahwa pengeluaran untuk investasi menunjukkan keseriusan manajemen dalam mengembangkan perusahaan. Dengan adanya kebijakan investasi yang dilakukan oleh perusahaan, diharapkan perusahaan akan mendapatkan return dalam jangka waktu tertentu. Hal ini ini akan di respon baik oleh pasar dan harga saham sebagai indikator dari nilai perusahaan akan meningkat (Wijaya \& Suganda, 2020).

\subsubsection{Corporate Social Resposibility (CSR)}

Pemerintah mewajibkan perusahaan untuk melaksanakan tanggung jawab sosial perusahaan sesuai dengan Undang-Undang Perseroan Terbatas (UUPT) Nomor 40 Tahun 2007. Salah satu kegiatannya adalah pelaksanaan tanggung jawab sosial perusahaan. Tanggung jawab sosial perusahaan merupakan tanggung jawab perusahaan terhadap lingkungan masyarakat, melindungi dan mengembangkan kesejahteraan masyarakat, membawa manfaat bagi perusahaan sekaligus sebagai sarana untuk membangun reputasi dan meningkatkan kinerja perusahaan yang unggul dalam persaingan.

Menurut Iskandar (2016) CSR merupakan komitmen perusahaan dan dunia usaha untuk berkontribusi dalam pembangunan ekonomi, memperhatikan tanggung jawab sosial perusahaan dan menekankan keseimbangan antara kepedulian ekonomi, sosial dan lingkungan. CSR adalah suatu konsep yang mendorong organisasi untuk mempertimbangkan kepentingan sosial dengan mengambil tanggung jawab atas dampak kegiatan organisasi terhadap konsumen, karyawan, pemegang saham, masyarakat, dan lingkungan dalam semua aspek operasi.

\subsubsection{Risiko Bisnis (Business Risk)}

Risiko bisnis dapat dijelaskan sebagai ketidakpastian dalam estimasi laba rugi operasi di masa depan perusahaan. Risiko bisnis dapat mempengaruhi kelangsungan hidup perusahaan, dimana perusahaan memiliki kemampuan untuk membayar hutangnya. Perusahaan yang memiliki risiko bisnis yang lebih tinggi seringkali kurang mampu mengunakan utang dalam jumlah yang besar dalam pendanaan perusahaan karena untuk menghindari tidak terbayarnya hutang di masa depan (Oktafiani dkk, 2019).

Menurut Yunita \& Aji (2018) risiko bisnis adalah salah satu risiko aset perusahaan yang akan dihadapi perusahaan jika menggunakan utang yang berlebihan akibat beban biaya utang yang dilakukan perusahaan. Ratri \& Christianti (2017) menambahkan bahwa risiko bisnis mengacu pada risiko perusahaan dimana perusahaan tidak dapat membayar biaya operasionalnya dan dipengaruhi oleh kestabilan pendapatan dan biaya. Dibandingkan dengan perusahaan dengan risiko bisnis yang lebih rendah, risiko bisnis cenderung menghindari pembiayaan utang. Sedangkan menurut Setiawan dkk. (2017) mengatakan bahwa risiko bisnis adalah ketidakpastian yang melekat pada pengembalian yang diharapkan atas aset masa depan yang dihadapi perusahaan.

\subsubsection{Nilai Perusahaan}

Nilai perusahaan merupakan gambaran para investor untuk melihat kinerja dan prospek perusahaan di masa yang akan datang. Semakin meningkat harga saham, maka akan meningkatkan nilai perusahaan (Ibrahim, 2017). Menurut Rosikah dkk. (2018) nilai perusahaan merupakan keseluruhan nilai aset yang dimiliki oleh perusahaan yang 
terdapat di pasar modal. Nilai perusahaan dapat dijadikan sebagai tolak ukur untuk melihat perkembangan perusahaan dengan tujuan untuk meningkatkan kepercayaan para pemegang saham, sehingga mampu menarik minat para investor untuk berinvestasi (Risma \& Regi, 2017). Kalsum (2017) menjelaskan bahwa nilai perusahaan merupakan harga yang bersedia dibayar oleh calon pembeli jika perusahaan tersebut dijual.

\subsection{Hipotesis}

2.2.1. Pengaruh Market to Book Value of Equity (MBVE) terhadap Nilai Perusahaan (PBV)

MBVE merupakan proksi pengukuran IOS yang berbasis harga. Proksi ini berhubungan dengan keputusan investasi perusahaan terhadap pihak internal dan eksternal (Rini \& Mimba, 2019). Rencana pada pengeluaran manajemen untuk di masa depan dan pengeluaran di masa sekarang diharapkan dapat memiliki pengembalian yang lebih tinggi dari modal yang sudah dikeluarkan oleh manajemen (Rini \& Mimba, 2019). Penelitian yang dilakukan oleh Hamidah \& Umdiana (2017) menyatakan bahwa adanya pengaruh positif dari IOS terhadap nilai perusahaan. Dari hasil penelitian ini memiliki arti bahwa pertambahan kekayaan atau aset pada perusahaan cenderung terjadi pada perusahaan yang banyak melakukan investasi. Adapun pada penelitian yang dilakukan Frederica (2019) menyatakan bahwa ada pengaruh MBVE sebagai proksi dari IOS terhadap nilai perusahaan.

\section{$\mathrm{H}_{1}$ : Market to Book Value of Equity (MBVE) Berpengaruh terhadap Nilai Perusahaan (PBV)}

\subsubsection{Pengaruh Capital Expenditure to Book Value Assets (CA/BVA) terhadap Nilai Perusahaan (PBV)}

CA/BVA merupakan proksi pengukuran IOS yang berbasis investasi. Dalam teori sinyal menjelaskan bahwa pengeluaran pada modal perusahaan merupakan sesuatu yang penting dalam meningkatkan nilai perusahaan, karena semua macam jenis investasi yang dilakukan perusahaan akan memberikan sinyal positif terhadap pertumbuhan dan pendapatan perusahaan yang berdampak pada meningkatnya harga saham dimana harga saham adalah indikator dari nilai perusahaan (Putri \& Setiawan, 2019). Adapun penelitian yang dilakukan oleh Latifudin dkk. (2017) menyatakan bahwa CA/BVA memiliki pengaruh yang positif dan signifikan terhadap R\&D yang merupakan variabel intervening terhadap nilai perusahaan.

\section{$\mathrm{H}_{2}$ : Capital Expenditure to Book Value Assets (CA/BVA) Berpengaruh terhadap Nilai Perusahaan (PBV)}

\subsubsection{Pengaruh Corporate Social Responsibility (CSR) terhadap Nilai Perusahaan} (PBV)

Berdasarkan hasil dari teori stakeholders dan pengungkapan ini dapat berdampak positif terhadap nilai perusahaan (Li, 2017). Hal ini berarti semakin baik penerapan CSR oleh perusahaan maka nilai perusahaan akan semakin meningkat. Adapun penelitian yang dilakukan oleh Chen \& Lee (2017) menyatakan bahwa CSR tidak berkontribusi atau tidak berpengaruh untuk meningkatkan nilai perusahaan.

$\mathrm{H}_{3}$ : Corporate Social Responsibility (CSR) Tidak Berpengaruh terhadap Nilai Perusahaan (PBV) 


\subsubsection{Pengaruh Risiko Bisnis terhadap Nilai Perusahaan (PBV)}

Sesuai dengan teori trade off yang menyatakan bahwa semakin besar hutang dalam hal ini risiko bisnis, maka semakin besar pula resiko yang akan ditanggung oleh perusahaan sehingga menyebabkan nilai perusahaan menurun. Hal ini dikarenakan biaya bunga tetap yang harus dibayarkan akan meningkatkan risiko dan pendapatan yang diperoleh akan berkurang karena risiko yang terlibat timbul (Anggraeni dkk, 2018). Adapun penelitian yang dilakukan oleh Setyawulan dkk. (2020) menyatakan bahwa risiko bisnis tidak berpengaruh signifikan terhadap struktur modal sebagai variabel intervening terhadap nilai perusahaan.

\section{$\mathrm{H}_{4}$ : Risiko Bisnis Tidak Berpengaruh terhadap Nilai Perusahaan (PBV)}

\subsection{Model Penelitian}

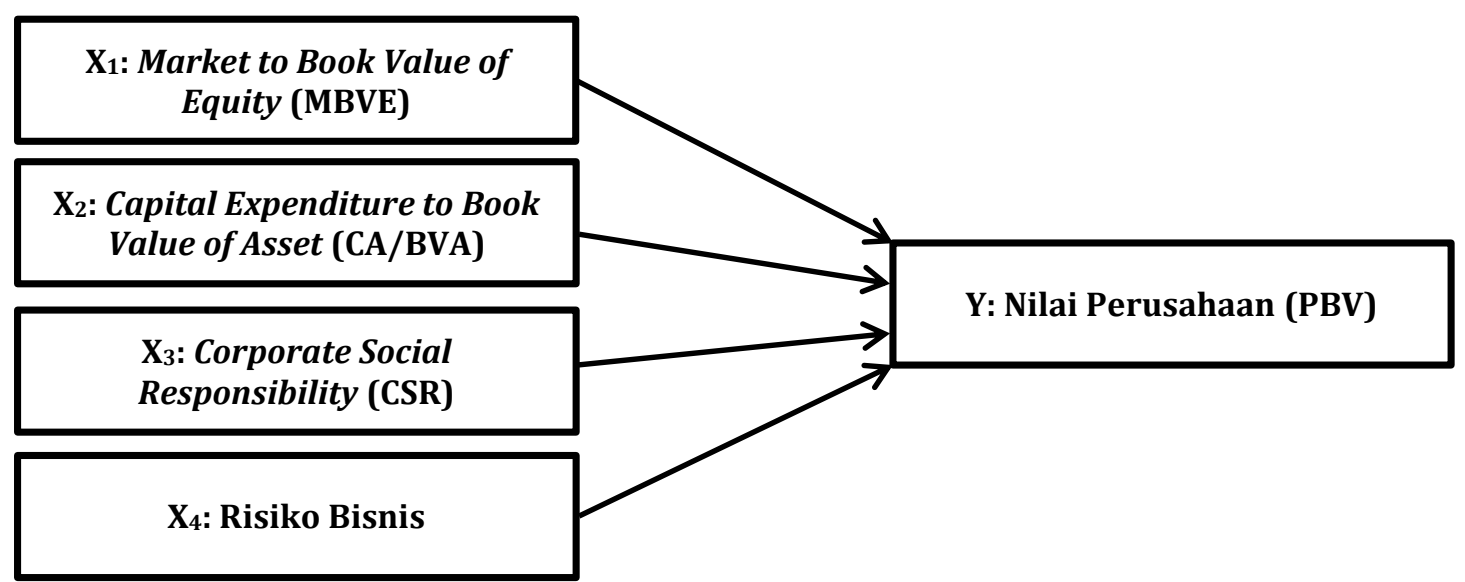

Gambar 1. Model Penelitian

\section{Metode Penelitian}

\subsection{Populasi, Sampel, dan Teknik Pengambilan Sampel \\ 3.1.1. Populasi}

Populasi adalah keseluruhan dari karakteristik atau unit hasil pengukuran yang menjadi objek penelitian atau populasi merupakan objek atau subjek yang berada pada suatu wilayah dan memenuhi syarat-syarat tertentu berkaitan dengan masalah penelitian (Sitinjak, 2020). Populasi yang digunakan dalam penelitian ini adalah perusahaan sub sektor perbankan yang terdaftar di Bursa Efek Indonesia yang terdiri dari 45 perusahaan dari tahun 2015-2019.

\subsubsection{Sampel}

Teknik pengambilan sampel dalam penelitian ini dilakukan secara purposive sampling dengan tujuan mendapatkan sampel yang representif sesuai dengan karakteristik yang ditentukan peneliti (Sitinjak, 2020). Adapun karakteristik tertentu yang digunakan untuk dijadikan sampel adalah sebagai berikut:

1. Perusahaan sub sektor perbankan yang terdaftar di Bursa Efek Indonesia periode 2015-2019

2. Perusahaan menerbitkan laporan keuangan tahunan perusahaan lengkap dan tepat waktu yang berakhir 31 Desember dari tahun 2015-2019

3. Perusahaan yang tidak mengalami delisting dari tahun 2015-2019

4. Perusahaan yang sudah listing sebelum tahun periode penelitian

5. Perusahan sampel memiliki semua data yang diperlukan secara lengkap 
6. Perusahaan memiliki data harga penutupan saham akhir tahun dimana saham tersebut aktif diperdagangkan selama periode penelitian

7. Perusahaan yang mengungkapkan CSR

Pada perusahaan sub sektor perbankan yang terdaftar di Bursa Efek Indonesia terdiri dari 45 perusahaaan yang berdasarkan data terbaru, namun hanya 39 perusahaan pada sub sektor perbankan yang memenuhi kriteria sebagai sampel pada tahun 2015-2019.

\subsection{Analisis Data}

\subsubsection{Analisis Regresi Linear Berganda}

Analisis regresi berganda adalah suatu alat analisis peramalan nilai pengaruh dua variabel bebas atau lebih terhadap variabel terikat untuk membuktikan ada atau tidaknya hubungan fungsi atau hubungan antara dua variabel bebas atau lebih dengan satu variabel terikat (Ghozali, 2016).

\subsubsection{Uji Asumsi Klasik}

\subsubsection{Uji Normalitas}

Uji Normalitas merupakan sebuah uji yang dilakukan dengan tujuan untuk menilai sebaran data pada sebuah kelompok data atau variabel, apakah sebaran data tersebut berdistribusi normal ataukah tidak (Ghozali, 2016). Tujuan uji normalitas mengetahui adanya variabel pengganggu yang berdistribusi secara normal atau tidak dalam model regresi. Untuk mengetahui data berdistribusi secara normal atau tidak, dapat dilakukan Kolmogorov Smirnov Test, dimana dinyatakan berdistribusi secara normal apabila nilai prob. $>0,05$ (Ghozali, 2016).

\subsubsection{Uji Multikolinearitas}

Uji multikolinearitas merupakan uji yang dilakukan untuk memastikan apakah di dalam sebuah model regresi ada interkorelasi atau kolinearitas antar variabel bebas (Ghozali, 2016). Tujuan uji multikolinearitas untuk mengetahui adanya korelasi antar variabel bebas dalam model regresi. Cara untuk mengetahui adanya korelasi antar variabel bebas adalah dengan melihat nilai Variance Inflation Factor (VIF), dimana nilai cut off yang biasa digunakan dalam menunjukkan adanya multikolinearitas adalah nilai tolerance $<0,10$ atau sama dengan nilai VIF $>10$ (Ghozali, 2016).

\subsubsection{Uji Autokorelasi}

Uji autokorelasi merupakan sebuah analisis statistik yang dilakukan untuk mengetahui adakah korelasi variabel yang ada di dalam model prediksi dengan perubahan waktu (Ghozali, 2016). Tujuan dari uji autokorelasi adalah untuk menunjukkan korelasi antara kesalahan perancu selama "t" dan kesalahan selama "t1" dalam model regresi. Salah satu cara untuk menentukan ada tidaknya autokorelasi adalah dengan menggunakan uji berjalan yang merupakan bagian dari uji non-parametrik untuk menentukan apakah terdapat korelasi acak atau sistematis pada data residual. Jika itu adalah hasil Asymp. Sig. (2-tailed) lebih kecil dari 0,05, maka data tidak terkena masalah autokorelasi (Ghozali, 2016).

\subsubsection{Uji Heteroskedastisitas}

Uji Heteroskedastisitas adalah uji yang menilai apakah ada ketidaksamaan varian dari residual untuk semua pengamatan pada model regresi linear. Uji ini merupakan salah satu dari uji asumsi klasik yang harus dilakukan pada regresi linear (Ghozali, 2016). Uji Heteroskedastisitas untuk melihat adanya ketidaksamaan variance dari residual satu pengamatan ke pengamatan lain dalam model regresi. Apabila hasil dari satu pengamatan ke pangamatan lain tetap maka tidak terjadi 
heteroskedastisitas atau disebut dengan homokedastisitas, sedangkan apabila hasil dari satu pengamatan ke pengamatan lain berubah maka terjadi heteroskedastisitas.

Hasil yang baik adalah hasil yang menunjukkan homokedastisitas atau tidak terjadi heteroskedastisitas (Ghozali, 2016). Dalam penelitian ini untuk menguji ada tidaknya heteroskedastisitas. maka dilakukan dengan uji glejser. Uji glejser menyatakan bahwa variansi merupakan fungsi dari variabel independen, apabila nilai signifikansi dari variabel independen di bawah 0,05, maka terjadi heteroskedastisitas, sedangkan apabila berada di atas 0,05, maka tidak terjadi heteroskedastisitas (homokedastisitas) (Ghozali, 2016).

\subsubsection{Uji Hipotesis}

\subsubsection{Uji Koefisien Determinasi}

Uji koefisien determinasi bertujuan untuk mengukur seberapa besar variabel independen berpengaruh terhadap variabel dependen. Nilai dari $\mathrm{R}^{2}$ adalah antara nol dan satu, dimana nilai $\mathrm{R}^{2}$ yang kecil menunjukkan bahwa kemampuan variabel independen dalam menjelaskan variabel dependen sangat terbatas. Apabila nilai $\mathrm{R}^{2}$ mendekati angka 1, maka menunjukkan bahwa kemampuan variabel independen dalam menjelaskan dependen sangat luas atau dapat mencakup seluruh informasi (Ghozali, 2016).

\subsubsection{Uji Parsial (Uji T)}

Uji T adalah uji untuk mengukur seberapa jauh pengaruh dari setiap variabel independen terhadap variabel dependen. Uji $\mathrm{T}$ dilakukan dengan cara membandingkan nilai signifikansi yang diperoleh. Apabila nilai signifikansi $<0,05$ menunjukkan bahwa variabel independen berpengaruh secara signifikan terhadap variabel dependen.

\section{Hasil dan Pembahasan}

\subsection{Uji Asumsi Klasik}

\subsubsection{Uji Normalitas}

Tabel 1. Hasil Kolmogorov-Smirnov Test One-Sample Kolmogorov-Smirnov Test

\begin{tabular}{ccc}
\multicolumn{2}{c}{ One-Sample Kolmogorov-Smirnov Test } \\
\hline \multirow{2}{*}{ N } & Unstandardized Residual \\
Normal Parameters ${ }^{\mathrm{a}, \mathrm{b}}$ & Mean & 195 \\
& Std. Deviation & 0,000 \\
Most Extreme Differences & Absolute & 0,649 \\
& Positive & 0,042 \\
& Negative & 0,029 \\
Test Statistic & & $-0,042$ \\
Asymp. Sig. (2-Tailed) & & 0,042 \\
\hline
\end{tabular}

Sumber: Olah Data (2021)

Hasil uji kolmogorov smirnov pada tabel 1 dapat disimpulkan bahwa nilai signifikansi sebesar 0, 200 dengan standar yang digunakan 5\% $(0,05)$. Artinya, residual menyebar normal karena nilai signifikan 0,200 >0,05. 


\subsubsection{Uji Heteroskedastisitas}

Tabel 2. Hasil Glejser Test

\begin{tabular}{|c|c|c|c|c|c|c|}
\hline & \multirow[t]{2}{*}{ Model } & \multicolumn{2}{|c|}{ Unstandardized Coefficients } & \multirow{2}{*}{$\begin{array}{c}\begin{array}{c}\text { Standardized } \\
\text { Coefficients }\end{array} \\
\text { Beta }\end{array}$} & \multirow[t]{2}{*}{$\mathrm{t}$} & \multirow[t]{2}{*}{ Sig. } \\
\hline & & B & Std. Error & & & \\
\hline \multirow[t]{5}{*}{1} & (Constant) & 0,563 & 0,085 & & 6,630 & 0,000 \\
\hline & MBVE & $-0,005$ & 0,013 & $-0,029$ & $-0,385$ & 0,700 \\
\hline & $\mathrm{CA} / \mathrm{BVA}$ & 0,019 & 0,011 & 0,173 & 1,678 & 0,095 \\
\hline & CSR & $-0,018$ & 0,011 & $-0,121$ & $-1,689$ & 0,093 \\
\hline & Risiko Bisnis & $-0,024$ & 0,014 & $-0,172$ & $-1,727$ & 0,086 \\
\hline
\end{tabular}

Sumber: Olah Data (2021)

Hasil pengujian heteroskedastisitas pada tabel 2 menunjukkan bahwa tidak adanya hubungan yang signifikan antara seluruh variabel independen terhadap nilai absolute residual (Res2) yaitu MBVE $(0,700>0,05)$, CA/BVA $(0,095>0,05), \operatorname{CSR}(0,093$ $>0,05)$, dan risiko bisnis $(0,086>0,05)$. Kesimpulannya dalam uji heteroskedastisitas penelitian ini tidak terdapat masalah heteroskedastisitas.

\subsubsection{Uji Autokorelasi}

Tabel 3. Hasil Run Test

\begin{tabular}{cc|}
\hline & Run Test \\
Test Value & Unstandardized Residual \\
Cases < Test Value & 0,020 \\
Cases > = Test Value & 97 \\
Total Vases & 98 \\
Number of Runs & 195 \\
Z & 45 \\
Asymp. Sig. (2-Tailed) & $-7,682$ \\
\hline
\end{tabular}

Sumber: Olah Data (2021)

Berdasarkan hasil uji autokorelasi dengan run test pada tabel 3 menunjukkan bahwa nilai Asymp. Sig. (2-tailed) sebesar 0,100 > dari 0,05. Artinya model regresi bebas dari masalah autokorelasi.

\subsubsection{Uji Multikolinearitas}

Tabel 4. Hasil Uji Multikolinearitas

\begin{tabular}{|c|c|c|c|c|c|c|c|c|}
\hline & \multirow[t]{2}{*}{ Model } & \multicolumn{2}{|c|}{$\begin{array}{c}\text { Unstandardized } \\
\text { Coefficients }\end{array}$} & \multirow{2}{*}{$\begin{array}{c}\text { Standardized } \\
\text { Coefficients }\end{array}$} & \multirow[t]{2}{*}{$\mathrm{T}$} & \multirow[t]{2}{*}{ Sig. } & \multicolumn{2}{|c|}{ Collinearity Statistic } \\
\hline & & B & $\begin{array}{c}\text { Std. } \\
\text { Error }\end{array}$ & & & & Tolerance & VIF \\
\hline \multirow[t]{5}{*}{1} & (Constant) & $-1,176$ & 0,151 & & $-1,171$ & 0,243 & & \\
\hline & MBVE & 0,055 & 0,022 & 0,179 & 2,428 & 0,016 & 0,908 & 1,101 \\
\hline & CA/BVA & $-0,021$ & 0,020 & $-0,104$ & $-1,020$ & 0,309 & 0,476 & 2,101 \\
\hline & CSR & $-0,038$ & 0,019 & $-0,141$ & $-1,999$ & 0,047 & 0,985 & 1,015 \\
\hline & Risiko & 0,012 & 0,024 & 0,049 & 0,496 & 0,621 & 0,512 & 1,953 \\
\hline
\end{tabular}

Sumber: Olah Data (2021)

Hasil dari uji multikolinearitas dapat dilihat pada tabel 4 dimana nilai VIF dengan ketentuan $<10$, maka disimpulkan bahwa tidak terdapat masalah multikolinearitas diantara variabel independen. Apabila nilai VIF > 10, maka dapat disimpulkan bahwa asumsi model tersebut terdapat masalah multikolinearitas (Aslikhan, 2018). 
Berdasarkan tabel 4 nilai VIF dari variabel independen MBVE, CA/BVA, CSR, dan risiko bisnis dapat disimpulkan bahwa tidak terjadi masalah multikolinearitas, sebab nilai VIF dari variabel MBVE, CA/BVA, CSR, dan risiko bisnis lebih keci dari dari 10.

\subsection{Uji Regresi Linear Berganda}

Pada bagian ini dilakukan analisis data mengenai pengaruh MBVE, CA/BVA, CSR, risiko bisnis secara parsial terhadap nilai perusahaan. Berdasarkan data hasil penelitian tersebut, maka secara lengkap hasil analisa regresi linear berganda yang telah dilakukan dapat dilihat pada tabel di bawah ini:

Tabel 5. Hasil Uji Regresi Linear Berganda

\begin{tabular}{|c|c|c|c|c|c|c|}
\hline \multicolumn{7}{|c|}{ Coefficients ${ }^{\mathbf{a}}$} \\
\hline & \multirow[b]{2}{*}{ Model } & \multicolumn{2}{|c|}{$\begin{array}{l}\text { Unstandardized } \\
\text { Coefficients }\end{array}$} & \multirow{2}{*}{$\begin{array}{c}\text { Standardized } \\
\text { Coefficients } \\
\text { Beta }\end{array}$} & \multirow[b]{2}{*}{$\mathrm{T}$} & \multirow[b]{2}{*}{ Sig. } \\
\hline & & $\mathrm{B}$ & Std. Error & & & \\
\hline \multirow[t]{5}{*}{1} & (Constant) & $-0,176$ & 0,151 & & $-1,171$ & 0,243 \\
\hline & MBVE & 0,055 & 0,022 & 0,179 & 2,428 & 0,016 \\
\hline & CA/BVA & $-0,021$ & 0,020 & $-0,104$ & $-1,020$ & 0,309 \\
\hline & CSR & $-0,038$ & 0,019 & $-0,141$ & $-1,999$ & 0,047 \\
\hline & Risiko Bisnis & 0,012 & 0,024 & 0,049 & 0,496 & 0,621 \\
\hline
\end{tabular}

Sumber : Olah Data (2021)

Konstanta $(\alpha)$ sebesar -0,176. Artinya jika variabel MBVE, CA/BVA, CSR, dan risiko bisnis memiliki nilai sebesar 0 , maka tingkat nilai perusahaan sebesar $-0,176$. Konstanta adalah nilai yang tetap walaupun variabel lain nilainya berubah. Konstanta negatif tidaklah menjadi persoalan selama nilai varian independen tidak nol. Pada dasarnya regresi digunakan untuk memprediksi nilai dependen berdasarkan nilai perubahan independen, maka seharusnya yang menjadi perhatian adalah nilai independen bukan nilai konstanta tersebut (Yulia dkk, 2020).

Nilai koefisien MBVE sebesar 0,055 merupakan besarnya kontribusi variabel MBVE yang mempengaruhi PBV. Jika variabel MBVE mengalami kenaikan satu satuan, maka PBV akan naik sebesar 0,055 dan sebaliknya. Nilai koefisien CA/BVA sebesar -0,021 merupakan besarnya kontribusi variabel CA/BVA yang mempengaruhi PBV. Jika variabel CA/BVA mengalami kenaikan satu satuan, maka PBV akan turun sebesar -0,021 dan sebaliknya.

Nilai koefisien CSR sebesar -0,038 merupakan besarnya kontribusi variabel CSR yang mempengaruhi PBV. Jika CSR mengalami kenaikan satu satuan, maka PBV turun sebesar -0,038 dan sebaliknya. Nilai koefisien risiko bisnis sebesar 0,012 merupakan besarnya kontribusi variabel risiko bisnis yang mempengaruhi PBV. Jika variabel risiko bisnis mengalami kenaikan satu satuan, maka PBV akan naik sebesar 0,012 dan sebaliknya.

\subsection{Uji Hipotesis}

\subsubsection{Uji Koefisien Determinasi}

Tabel 6. Hasil Uji Koefisien Determinasi

\begin{tabular}{|c|c|c|c|c|}
\hline \multicolumn{5}{|c|}{ Model Summary $^{\mathbf{b}}$} \\
\hline Model & $\mathrm{R}$ & R-Square & $\begin{array}{c}\text { Adjusted R- } \\
\text { Square }\end{array}$ & $\begin{array}{c}\text { Std. Error of The } \\
\text { Estimate }\end{array}$ \\
\hline 1 & 0,254 & 0,064 & 0,045 & 0,65654 \\
\hline
\end{tabular}

Sumber: Olah Data (2021)

Berdasarkan tabel 6 diketahui nilai koefisien determinasi (R-Square) yang diperoleh sebesar 0,064. Hal ini menunjukkan bahwa PBV sebagai variabel terikat pada 
sub sektor perbankan yang terdaftar di Bursa Efek Indonesia dapat dipengaruhi oleh MBVE, CA/BVA, CSR, dan risiko bisnis sebesar 6,4\%.

\subsubsection{Uji Parsial (Uji T)}

Tabel 7. Hasil Uji Parsial (Uji T)

\begin{tabular}{|c|c|c|c|c|c|c|}
\hline \multicolumn{7}{|c|}{ Coefficienta } \\
\hline & \multirow[t]{2}{*}{ Model } & \multicolumn{2}{|c|}{ Unstandardized Coefficients } & \multirow{2}{*}{$\begin{array}{c}\begin{array}{c}\text { Standardized } \\
\text { Coefficients }\end{array} \\
\text { Beta }\end{array}$} & \multirow[t]{2}{*}{$\mathrm{t}$} & \multirow[t]{2}{*}{ Sig. } \\
\hline & & B & Std. Error & & & \\
\hline \multirow[t]{5}{*}{1} & (Constant) & $-0,176$ & 0,151 & & $-1,171$ & 0,243 \\
\hline & MBVE & 0,055 & 0,022 & 0,179 & 2,428 & 0,016 \\
\hline & $\mathrm{CA} / \mathrm{BVA}$ & $-0,021$ & 0,020 & $-0,104$ & $-1,020$ & 0,309 \\
\hline & CSR & $-0,038$ & 0,019 & $-0,141$ & $-1,999$ & 0,047 \\
\hline & Risiko Bisnis & 0,012 & 0,024 & 0,049 & 0,496 & 0,621 \\
\hline
\end{tabular}

Sumber: Olah Data (2021)

Tabel 7 di atas menunjukkan hasil uji parsial dengan penjelasan sebagai berikut:

1. Pengaruh Market to Book Value Equity (MBVE) terhadap Nilai Perusahaan (PBV).

Berdasarkan hasil uji parsial diperoleh nilai koefisien sebesar 0,055 dan nilai signifikansi $0,016<0,05$. Artinya, semakin tinggi MBVE, maka nilai perusahaan juga semakin meningkat. Berdasarkan hasil tersebut, maka hipotesis pertama yang mengatakan MBVE berpengaruh terhadap nilai perusahaan diterima.

2. Pengaruh Capital Expenditure to Book Value of Asset (CA/BVA) terhadap Nilai Perusahaan (PBV)

Berdasarkan hasil uji parsial diperoleh nilai koefisien sebesar -0,021 dan nilai signifikansi 0,309 >0,05. Artinya, semakin tinggi CA/BVA, maka nilai perusahaan juga menurun. Berdasarkan hasil tersebut, maka hipotesis kedua yang mengatakan CA/BVA berpengaruh terhadap nilai perusahaan ditolak.

3. Pengaruh Corporate Social Responbility (CSR) terhadap Nilai Perusahaan (PBV)

Berdasarkan hasil uji parsial diperoleh nilai koefisien sebesar $-0,038$ dan nilai signifikansi $0,047<0,05$. Artinya, semakin tinggi CSR, maka nilai perusahaan juga menurun. Berdasarkan hasil tersebut, maka hipotesis ketiga yang mengatakan CSR tidak berpengaruh terhadap nilai perusahaan diterima.

4. Pengaruh Risiko Bisnis terhadap Nilai Perusahaan (PBV)

Berdasarkan hasil uji parsial diperoleh nilai koefisien sebesar 0,012 dan nilai signifikansi 0,621 <0,05. Artinya, semakin tinggi risiko bisnis, maka nilai perusahaan juga meningkat. Berdasarkan hasil tersebut, maka hipotesis keempat yang mengatakan risiko bisnis tidak berpengaruh terhadap nilai perusahaan ditolak.

\subsection{Pembahasan}

\subsubsection{Pengaruh Market to Book Value Equity (MBVE) terhadap Nilai Perusahaan (PBV)}

Hasil penelitian menunjukkan dengan nilai koefisien sebesar 0,055 dan nilai signifikansi sebesar 0,016 $(0,016<0,05)$ yang berarti MBVE berpengaruh terhadap nilai perusahaan. Rasio ini mencerminkan bahwa nilai pasar melalui return dari investasi perusahaan di masa depan akan lebih besar dari return yang diharapkan dari ekuitasnya. Penelitian yang dilakukan oleh Syardiana (2015) menyebutkan bahwa IOS berdasarkan proksi harga pada rasio MBVE berpengaruh positif terhadap nilai perusahaan. Apabila perusahaan mampu memaksimumkan kemampuannya melalui investasi-investasi dalam menghasilkan laba sesuai dengan jumlah dana yang terikat, maka dapat meningkatkan nilai perusahaan. 
MBVE merupakan proksi IOS berdasarkan harga yang melihat pertumbuhan perusahaan dari kemampuan perusahaan dalam mendapatkan dan mengelola modal. Untuk itu, hasil ini memberikan pengertian bahwa kesempatan investasi yang dilihat dari kemampuan perusahaan dalam mendapatkan dan mengelola modal berpengaruh dan signifikan terhadap nilai perusahaan (Sudiani \& Darmayanti, 2018).

IOS akan memberikan informasi tentang prospek pendapatan yang diperoleh di masa yang akan datang. Hasil penelitian menunjukkan bahwa apabila IOS meningkat, maka nilai perusahaan akan semakin meningkat dikarenakan semakin tinggi kesempatan yang dimiliki perusahaan untuk melakukan investasi dan diharapkan mendapatkan return yang lebih tinggi. IOS menunjukkan potensi pertumbuhan perusahaan, sehingga menjadi daya tarik investor karena akan menguntungkan investor kedepannya. Secara umum, IOS menggambarkan tentang luasnya peluang investasi bagi suatu perusahaan, namun sangat tergantung pada pengeluaran perusahaan di masa yang akan datang (Hidayah, 2015).

Apabila dilihat dari teori sinyal, terjadinya pengeluaran untuk investasi oleh perusahaan akan memberikan sinyal yang positif tentang pertumbuhan perusahaan di masa yang akan datang, sehingga akan meningkatkan harga saham yang merupakan indikator nilai perusahaan (Suartawan \& Yasa, 2016). Hal ini disebabkan oleh persepsi dari para pelaku pasar modal yang melihat bahwa dengan adanya pengeluaran untuk investasi berarti menunjukkan keseriusan manajemen dalam mengembangkan perusahaan.

Dengan adanya kebijakan investasi yang dilakukan oleh perusahaan, maka diharapkan dalam jangka waktu tertentu perusahaan akan mendapatkan return dari hasil investasinya sehingga perusahaan akan semakin tumbuh. Hal ini akan direspon positif oleh pasar dan harga saham sebagai indikator nilai perusahaan akan meningkat. Oleh karena itu, dengan meningkatnya kegiatan investasi yang dilakukan oleh perusahaan, maka akan meningkatkan nilai perusahaan. membuktikan bahwa perbedaan nilai pasar ekuitas terhadap nilai buku merupakan cerminan peluang investasi. Proksi ini dapat mencerminkan besarnya return dari aktiva yang ada dan investasi yang diharapkan di masa yang akan datang dapat melebihi return dari ekuitas yang diinginkan. Perusahaan yang tumbuh akan mempunyai nilai pasar yang relatif lebih tinggi dibandingkan dengan aktiva riilnya, karena rasio ini merupakan prospek pertumbuhan perusahaan parsial yang tergabung dalam harga saham, dan pertumbuhan akan lebih besar dari nilai pasar relatif terhadap aktiva-aktiva yang dimiliki.

Penelitian sejalan dengan penelitian yang dilakukan oleh Hidayah (2015), (Suartawan \& Yasa, 2016), Setiawan dkk. (2017), serta Sudiani \& Darmayanti, (2018) yang menyatakan bahwa IOS yang diproksikan dengan MBVE berpengaruh positif terhadap nilai perusahaan. Hal ini mengindikasikan bahwa perusahaan dengan nilai pasar yang tinggi dinilai baik oleh investor karena dapat memberikan return yang baik melalui harga saham yang tinggi. Begitupun pada penelitian yang dilakukan Frederica (2019) menyatakan bahwa ada pengaruh positif MBVE sebagai proksi dari IOS terhadap nilai perusahaan.

\subsubsection{Pengaruh Capital Expenditure to Book Value Assets (CA/BVA) terhadap Nilai Perusahaan (PBV)}

Hasil penelitian menunjukkan nilai koefisien sebesar $-0,021$ dan nilai signifikansi $0,309(0,309>0,05)$ yang berarti CA/BVA tidak berpengaruh terhadap nilai perusahaan. CA/BVA adalah rasio yang menunjukkan adanya aliran tambahan modal saham perusahaan untuk tambahan aktiva produktif sehingga berpotensi terhadap pertumbuhan perusahaan. Berdasarkan analisis yang dilakukan bahwa rasio CA/BVA 
tidak berpengaruh positif terhadap nilai perusahaan. Dikaitkan dengan analisis deskriptif hal ini menandakan bahwa perusahaan banyak mengalami penurunan nilai buku pada aset tetapnya dan sebagian perusahaan masih ada yang belum memanfaatkan tambahan modal saham untuk meningkatkan aktiva produktifnya dan menyebabkan penurunan pada nilai perusahaan (Agustina, 2016).

Perusahaan yang belum memanfaatkan tambahan modal saham untuk meningkatkan aktiva produktifnya juga akan berdampak pada investasi di perusahaan tersebut, karena para investor dapat melihat seberapa besar aliran modal tambahan suatu perusahaan dengan cara membagi capital asset dengan total asset. Semakin besar aliran tambahan modal saham, semakin besar kemampuan perusahaan untuk memanfaatkannya sebagai tambahan investasi sehingga perusahaan tersebut mempunyai kesempatan untuk tumbuh. Apabila perusahaan belum memanfaatkan tambahan modal saham, maka semakin kecil kemampuan perusahaan untuk memanfaatkan investasi sehingga perusahaan tersebut tidak mempunyai kesempatan untuk tumbuh. Hal ini bertentangan dengan teori yang dikemukkan oleh (Pratama, 2020) yang menyatakan bahwa investasi jangka panjang bertujuan untuk memaksimumkan kemakmuran pemegang saham atau nilai perusahaan. Jika perusahaan melakukan investasi dan investasi tersebut memberikan penambahan nilai yang lebih besar di masa yang akan datang, maka dapat meningkatkan nilai perusahaan.

CA/BVA memberikan informasi mengenai seberapa besar aliran tambahan modal perusahaan. Perusahaan dapat memanfaatkannya untuk mengetahui seberapa besar tambahan investasi aktiva produktifnya, sehingga potensi perusahaan dapat bertumbuh semakin besar. Sedangkan untuk para investor dapat menggunakan variabel ini untuk mengetahui seberapa besar prospek investasi perusahaan di masa mendatang. Melihat tambahan modal perusahaan karena dengan adanya pertumbuhan investasi perusahaan di masa mendatang akan meningkatkan kinerja perusahaan, dengan meningkatnya kinerja perusahaan akan berpengaruh kepada naiknya harga saham perusahaan dan harga saham yang tinggi akan berdampak pada meningkatnya keuntungan yang akan didapatkan oleh investor (Pratama, 2020)

Penurunan harga saham pada beberapa sektor perbankan akan berdampak pada laba yang dihasilkan. Setiap perusahaan pastinya menginginkan pertumbuhan harga saham yang cenderung meningkat akan menunjukkan prospek return yang lebih baik. Pertumbuhan harga saham merupakan kenaikan jumlah return dari waktu ke waktu. Hal ini membuktikan bahwa kesempatan memperoleh return di pasar modal tidak berkorelasi positif dengan besarnya aliran tambahan modal saham perusahaan (Agustina, 2016).

Perusahaan yang belum memanfaatkan tambahan modal saham untuk meningkatkan aktiva produktifnya juga akan berdampak pada investasi di perusahaan tersebut, karena para investor dapat melihat seberapa besar aliran modal tambahan suatu perusahaan dengan cara membagi capital asset dengan total aset. Semakin besar aliran tambahan modal saham, semakin besar kemampuan perusahaan untuk memanfaatkannya sebagai tambahan investasi sehingga perusahaan tersebut mempunyai kesempatan untuk tumbuh dan apabila perusahaan belum memanfaatkan tambahan modal saham semakin kecil kemampuan perusahaan untuk memanfaatkan investasi sehingga perusahaan tersebut tidak mempunyai kesempatan untuk tumbuh. Penelitian ini sejalan dengan penelitian Hidayah (2015) dan Agustina (2016) yang menyatakan bahwa CA/BVA tidak berpengaruh positif terhadap nilai perusahaan. 


\subsubsection{Pengaruh Corporate Social Responsibility (CSR) terhadap Nilai Perusahaan (PBV)}

Hasil penelitian menunjukkan dengan nilai koefisien sebesar -0,038 dan nilai signifikansi sebesar 0,047 $<0,05$ yang berarti CSR berpengaruh terhadap nilai perusahaan. Hal ini disebabkan karena fenomena yang mengungkapkan CSR berpengaruh terhadap nilai perusahaan yang diakibatkan oleh kecenderungan investor dalam membeli saham, tingginya pengungkapan CSR dan variabel pengungkapan CSR yang dapat diukur secara langsung investor lebih cenderung memilih untuk membeli dan menjual saham dengan melihat ekonomi pasar dan berita yang beredar. CSR merupakan strategi jangka panjang perusahaan dalam rangka menjaga lingkungan sekitar yang tidak dapat dirasakan dalam jangka yang pendek.

CSR adalah bentuk tanggung jawab sosial perusahaan terhadap stakeholders. Perusahaan yang melaksanakan CSR akan mendapat banyak keuntungan seperti kesetiaan pelanggan dan kepercayaan dari kreditor dan investor. Hal ini akan memicu keuangan perusahaan menjadi lebih baik sehingga laba perusahaan meningkat. Perusahaan yang memiliki kinerja sosial dan lingkungan yang baik akan direspon positif oleh investor, karena semakin tinggi pengungkapan CSR pada suatu perusahaan maka masyarakat dan lingkungan sekitar akan menilai positif perusahaan tersebut sehingga masyarakat akan membeli produk dari perusahaan itu, dengan begitu perusahaan akan mendapatkan banyak keuntungan dan mempunyai reputasi yang baik. Apabila perusahaan memiliki reputasi yang semakin baik maka akan mempengaruhi nilai dari perusahaan tersebut. Pengungkapan CSR yang dilakukan oleh perusahaan akan menciptakan citra yang baik terhadap perusahaan sehingga investor akan melihat hal ini sebagai hal yang positif untuk berinvestasi di perusahaan tersebut. Disamping itu, apabila perusahaan manufaktur mampu memperhatikan pengelolaan lingkungannya, maka keberadaan perusahaan tersebut akan direspon positif oleh masyarakat, sehingga citra atau image-nya meningkat yang akan diikuti dengan meningkatnya nilai perusahaan (Sartika, 2017).

Dalam stakeholder theory dijelaskan bahwa keberlangsungan perusahaan dipengaruhi oleh pihak stakeholder. Dari teori tersebut, perusahaan diharapkan dapat memenuhi harapan para stakeholder dengan melaksanakan program CSR yang diungkapkan dalam laporan tahunan perusahaan tersebut. sesuai dengan pasal 66 dan pasal 74 Undang-Undang No. 40 tahun 2007 mengenai Perseroan Terbatas, mengharuskan perusahaan untuk melakukan tanggung jawab sosial dan lingkungan karena CSR merupakan sebuah komitmen perseroan untuk berperan serta dalam pembangunan ekonomi berkelanjutan dapat meningkatkan kualitas kehidupan dan lingkungan yang bermanfaat bagi perusahaan maupun masyarakat pada umumnya. Pengungkapan program CSR perusahaan dapat mempercepat komunikasi antar perusahaan dengan stakeholder untuk meluruskan visi misi perusahaan berkaitan dengan praktik dan aktivitas bisnis perusahaan. Selain itu pula, pengungkapan program CSR dapat membentuk perusahaan yang berkesinambungan. Tujuan utama perusahaan adalah meningkatkan nilai perusahaan dengan memperhatikan dimensi ekonomi, sosial, dan lingkungan yang terdapat dalam pengungkapan CSR (Sartika, 2017).

Hasil ini sesuai penelitian Marius \& Masri (2017) yang membuktikan bahwa CSR berpengaruh positif terhadap nilai perusahaan. Penelitian terdahulu yang dilakukan oleh Rahayuningsih (2018) menunjukkan bahwa CSR berpengaruh signifikan positif terhadap nilai perusahaan. Adanya hubungan antara pertanggungjawaban sosial perusahaan dengan nilai perusahaan menunjukkan bahwa semakin luas pengungkapan CSR maka nilai perusahaan juga akan semakin meningkat. Tingginya nilai perusahaan menyebabkan keberadaan perusahaan tersebut akan lebih disorot oleh pihak stakeholders, apabila perusahaan dapat memaksimalkan manfaat yang diterima 
stakeholders, maka akan timbul kepuasan bagi stakeholders yang akan meningkatkan nilai perusahaan. Kesimpulannya bahwa dengan adanya CSR atau pertanggung jawaban sosial perusahaan yang baik, maka akan membuat nilai perusahaan juga akan dinilai dengan baik oleh para pihak investor atau secara sederhana dapat dikatakan bahwa nilai perusahaan juga akan meningkat (Ramona, 2017). Begitupun penelitian yang dilakukan oleh Chen \& Lee (2017) menyatakan bahwa CSR tidak berkontribusi atau tidak berpengaruh dalam meningkatkan nilai perusahaan.

\subsubsection{Pengaruh Risiko Bisnis terhadap Nilai Perusahaan (PBV)}

Hasil penelitian menunjukkan dengan nilai koefisien sebesar 0,012 dan nilai signifikansi sebesar 0,621 >0,05. Hal ini menunjukkan risiko bisnis tidak berpengaruh terhadap nilai perusahaan. Semakin tinggi risiko bisnis, maka akan semakin tinggi pula risiko kebangkrutan pada perusahaan tersebut begitu pula sebaliknya. Perusahaan yang menghadapi risiko bisnis tinggi sebagai akibat dari kegiatan operasinya, akan menghindari untuk menggunakan hutang yang tinggi dalam mendanai aktivanya.

Penelitian ini menemukan risiko bisnis tidak berpengaruh terhadap nilai perusahaan yang menunjukkan semakin tinggi risiko bisnis, maka akan semakin tinggi pula risiko kebangkrutan pada perusahaan tersebut begitu pula sebaliknya. Berdasarkan hasil penelitian ini menunjukkan bahwa penelitian ini sejalan dengan fenomena yang terjadi. Dimana penggunaan hutang yang tinggi, maka perusahaan akan memiliki risiko yang tinggi dapat dilihat berdasarkan total aset yang dimiliki perusahaan. Menurut catatan Bursa Efek Indonesia pada periode 2015-2019 terus mengalami peningkatan dengan penggunaan hutang yang tinggi sedangkan pendapatan laba yang rendah dapat mengakibatkan penurunan nilai perusahaaan. Berdasarkan teori yang digunakan penelitian ini sejalan dengan teori sinyal, risiko bisnis yang semakin tinggi, maka risiko perusahaan akan semakin tinggi, karena perusahaan yang memiliki risiko yang tinggi memberikan sinyal negatif bagi para investor untuk berinvestasi pada perusahaan tersebut (Fitriani, 2019).

Risiko bisnis merupakan risiko yang terjadi dan memiliki dampak terhadap kelangsungan hidup perusahaan atau saham-saham yang ada pada perusahaan. Dalam konsep risiko dan return, return dianggap mempunyai searah dengan yang dihadapi oleh sebuah investasi. Semakin tinggi risiko yang ditanggung investor, semakin tinggi pula return yang diharapkan oleh investor dari investasi tersebut. Apabila investasi tersebut dianggap tidak mengandung risiko, maka investor mengharapkan tingkat keuntungan bebas risiko. Investasi dalam saham dianggap investasi yang mengandung risiko (Fitriani, 2019).

Risiko tersebut berasal dari adanya ketidakpastian return yang akan diterima oleh investor, sehingga dari saham yang dimiliki investor diharapkan akan diperoleh suatu keuntungan yang lebih tinggi dari keuntungan bebas risiko. Risiko bisnis terjadi disebabkan karena penggunaan utang oleh perusahaan untuk aktivitas operasional. Penggunaan utang dalam pendanaan perusahaan awalnya akan meningkatkan kemampuan perusahaan dalam menghasilkan laba, karena tingkat suku bunga yang relatif rendah dibandingkan dengan kemampuan perusahaan dalam memperoleh laba. Jika ini berlangsung secara terus menerus, maka harga saham yang dihasilkan akan semakin kecil, yang disebabkan karena penggunaan hutang akan meningkatkan suku bunga dan risiko yang akan dihadapi semakin tinggi. Besar atau kecilnya risiko yang akan dihadapi perusahaan merupakan seberapa besar harapan atau keinginan keuntungan yang diperoleh. Dengan kondisi seperti ini, perusahaan sebaiknya menghindari penggunaan hutang, sebab akan mempengaruhi kemampuan perusahaan untuk menghasilkan keuntungan lebih kecil (Fitriani, 2019). 
Secara keseluruhan, semakin tinggi tingkat risiko suatu perusahaan, maka semakin tinggi keuntungan yang akan diperoleh perusahaan. Sebaliknya ketika risiko yang diperoleh rendah, maka pendapatan yang dihasilkan akan ikut rendah ketika tidak dikelola dengan baik. Hal ini sesuai dengan pernyataan yang dikemukakan oleh Arfan dkk. (2018) antara risiko bisnis dan return atau keuntungan bersifat searah, dimana semakin besar keinginan untuk memperoleh keuntungan akan diikuti oleh risiko yang besar pula. Hasil penelitian ini sejalan dengan penelitian Anggraeni dkk. (2018) bahwa risiko bisnis berpengaruh positif terhadap nilai perusahaan.

\section{Kesimpulan dan Saran}

\subsection{Kesimpulan}

Berdasarkan hasil pengujian dan pembahasan yang telah dilakukan, maka terdapat beberapa kesimpulan yang dapat diambil dari penilitian ini yaitu: pertama, MBVE berpengaruh terhadap nilai perusahaan pada sub sektor perbankan yang terdaftar di Bursa Efek Indonesia. Kedua, CA/BVA tidak berpengaruh terhadap nilai perusahaan pada sub sektor perbankan yang terdaftar di Bursa Efek Indonesia. Ketiga, CSR tidak berpengaruh terhadap nilai perusahaan pada sub sektor perbankan yang terdaftar di Bursa Efek Indonesia. Keempat, risiko bisnis berpengaruh terhadap nilai perusahaan pada sub sektor perbankan yang terdaftar di Bursa Efek Indonesia

\subsection{Saran}

Berdasarkan hasil penelitian di atas, maka saran yang dapat peneliti berikan adalah:

1. Bagi peneliti selanjutnya alangkah lebih baik menggunakan ketiga proksi IOS yaitu IOS berdasarkan harga, IOS berdasarkan investasi, dan IOS berdasarkan varian agar dapat membandingkan hasil dari ketiga proksi tersebut. Penelitian selanjutnya juga diharapkan menggunakan pengukuran yang lain dari setiap proksi untuk mendapatkan hasil yang lebih baik.

2. Bagi pihak perusahaan hendaknya tetap memperhatikan pentingnya tanggung jawab sosial perusahaan dan sebagai pertimbangan dalam pembuatan kebijakan perusahaan untuk lebih meningkatkan kepeduliannya terhadap lingkungan sosial. Selain itu, perusahaan diharapkan dapat mengelola risiko dengan baik secara efektif dengan meminimalisir penggunaan biaya yang terlalu tinggi. Hal tersebut dikarenakan perusahaan yang berskala besar seperti ini, penggunaan biaya yang terlalu tinggi akan memberikan dampak yang buruk untuk perusahaan sehingga akan berdampak pada kerugian perusahaan.

\section{Daftar Pustaka}

Agustina, D. (2016). Pengaruh Rasio Market to Book Value Of Equity, Capital Expenditure to Book Value Assets, dan Kepemilikan Manajerial terhadap Nilai Perusahaan Manufaktur Di Bursa Efek Indonesia Periode 2012-2014. Doctoral dissertation, STIE Perbanas Surabaya.

Anggraeni, S. B., Paramita, P. D., \& Oemar, A. (2018). Pengaruh Free Cash Flow, Risiko Bisnis dan Investment Opportunity Set terhadap Nilai Perusahaan dengan Kebijakan Hutang sebagai Variabel Intervening. Journal of Accounting, 4(4).

Arfan, M., Basri, H, Handayari, R., Shabri, M., Fahlevi, H., \& Dianah, A. (2017). Determinants of Cash Holding of Listed Manufacturing Companies in The Indonesian Stock Exchange. DLSU Business and Economics Review, 26(2), 1-12.

Bella, L. K. G., \& Suaryana, I. A. (2017). Pengaruh IOS dan Pengungkapan CSR pada Nilai Perusahaan dengan Pertumbuhan Perusahaan sebagai Variabel Pemoderasi. E-Jurnal Akuntansi, 19(1), 508-535.

Chen, R. C., \& Lee, C. H. (2017). The Influence of CSR on Firm Value: An Application of Panel 
Smooth Transition Regression on Taiwan. Applied Economics, 49(34), 3422-3434.

Dewi, R. M. (2019). Pengaruh Kebijakan Utang, Kebijakan Dividen dan Investment Opportunity Set (IOS) terhadap Nilai Perusahaan (Studi Empiris pada Perusahaan Manufaktur yang Terdaftar di BEI Periode Tahun 2017). Doctoral dissertation, University of Muhammadiyah Malang.

Frederica, D. (2019). The Impact of Investment Opportunity Set and Cost of Equity toward Firm Value Moderated By Information Technology Governance. International Journal of Contemporary Accounting, 1(1).

Fajriana, A., \& Priantinah, D. (2016). Pengaruh Corporate Social Responsibility, Keputusan Investasi, dan Struktur Modal terhadap Nilai Perusahaan. Nominal: Barometer Riset Akuntansi dan Manajemen, 5(2), 16-18.

Fitriani, A. (2019). Pengaruh Pertumbuhan Perusahaan, Risiko Bisnis, Suku Bunga, dan Keputusan Investasi terhadap Nilai Perusahaan dengan Kebijakan Hutang sebagai Variabel Moderating (Sektor Properti dan Real Estate Di Bursa Efek Indonesia Periode 2013-2017). Doctoral dissertation, IIB Darmajaya.

Giriati, Z. (2016). Free Cash Flow, Dividend Policy, Invesment Opportunity Set, Opportunistic Behavior and Firm's Value (A Study about Agency Theory). Procedia-Social and Behavioral Sciences, 219, 248-254.

Ghozali, I. (2016). Aplikasi Analisis Multivevariete dengan Program IBM SPSS (E. 8 (ed.)). Badan Penerbit Universitas Diponegoro.

Hakim, M. Z., \& Abbas, D. S. (2019). Pengaruh Ukuran Perusahaan, Struktur Modal, Likuiditas, Investment Opportunity Set (IOS), dan Profitabilitas terhadap Kualitas Laba (Perusahaan Makanan dan Minuman yang Terdaftar Di Bursa Efek Indonesia Tahun 2013-2017). Competitive: Jurnal Akuntansi dan Keuangan, 3(2), 26-51.

Hamidah, G., \& Umdiana, N. (2017). Pengaruh Profitabilitas dan Investment Opportunity Set (IOS) terhadap Nilai Perusahaan dengan Harga Saham sebagai Variabel Intervening. JAK (Jurnal Akuntansi) Kajian Ilmiah Akuntansi, 4(1).

Hidayah, N. (2015). Pengaruh Investment Opportunity Set (IOS) dan Kepemilikan Manajerial terhadap Nilai Perusahaan pada Perusahaan Properti dan Real Estate di Bursa Efek Indonesia. Junal Akuntansia, 19,(3).

Ibrahim, M. (2017). Capital Structure and Firm Value in Nigerian Listed Manufacturing Companies: an Empirical Investigation Using Tobin's Q Model. International Journal of Innovative Research in Social Sciences \& Strategic Management Techniques , 4(2), 112-125.

Iskandar, I. (2016). Pengaruh Penerapan Corporate Social Responsibility terhadap Profitabilitas Perusahaan. Forum Ekonomi, 18(1).

Kalsum, U. (2017). Pengaruh Pengungkapan Corporate Social Responsibility terhadap Nilai Perusahaan dengan Profitabilitas sebagai Variabel Moderasi (Studi Empiris pada Perusahaan Manufaktor yang Terdaftar Di BEI Periode 2012-2015).

Latifudin, M., Wahyudi, S., \& Muharam, H. (2017). The Effect of Capital Structure on Firm Value with The Mediation of R\&D as The Intervening Variable. International Journal of Economic Research, 14(15), 481-496.

Marius, M. E., \& Masri, I. (2017). Pengaruh Good Corporate Governance dan Corporate Social Responsibility terhadap Nilai Perusahaan. Konferensi Ilmiah Akuntansi IV, 1(2), 1-22.

Oktafiani, S. P., Atang Hermawan, S. E., MSIE, A., \& AK, B. S. S. (2019). Pengaruh Risiko Bisnis, Non-Debt Tax Shield, dan Tangibility Asset terhadap Struktur Modal (Studi pada Perusahaan Sub Sektor Otomotif dan Komponen yang terdaftar di Bursa Efek Indonesia periode 20132017). Doctoral dissertation, Perpustakaan FEB Unpas.

Pratama, A. S. I. (2020). Capital Expenditure, Struktur Modal, Leverage, Good Corporate Governance, Corporate Social Responsibility, dan Total Asset Turnover Dampaknya terhadap Nilai Perusahaan dengan Kinerja Keuangan sebagai Variabel Intervening pada Perusahaan Manufaktur Yang Terdaftar Di Bursa Efek Indonesia Periode 2017-2019. Doctoral dissertation, 
Universitas Pancasakti Tegal.

Putri, R. A. A., \& Setiawan, M. A. (2019). Pengaruh Investment Opportunity Set (IOS), Kebijakan Dividen, dan Opportunistic Behavior terhadap Nilai Perusahaan. Jurnal Eksplorasi Akuntansi, 1(3), 1392-1410.

Rahayuningsih, Y. (2018). Pengaruh Pengungkapan Corporate Social Responsibility (CSR) terhadap Nilai Perusahaan dengan Profitabilitas sebagai Variabel Moderasi.

Ramona, S. (2017). Pengaruh Corporate Social Responsibility terhadap Nilai Perusahaan dengan Profitabilitas sebagai Variabel Moderating (Studi Empiris Perusahaan Sektor Pertambangan yang Terdaftar di Bursa Efek Indonesia Periode 2011-2015). Doctoral dissertation, Universitas Pasir Pengaraian.

Ratri, A. M., \& Christianti, A. (2017). Pengaruh Size, Likuiditas, Profitabilitas, Risiko Bisnis, dan Pertumbuhan Penjualan terhadap Struktur Modal Pada Sektor Industri Properti. Jurnal Riset Manajemen dan Bisnis, 12(1), 13-24.

Rini, K. D., \& Mimba, N. P. (2019). Pengaruh Pengungkapan Corporate Social Responsibility, Investment Opportunity Set dan Struktur Modal pada Nilai Perusahaan. E-Jurnal Akuntansi, 28(3), 2019-2034.

Rosikah, D. K. P., Muthalib, D. A., Aziz, M. I., \& Rohansyah, M. (2018). Effect of Return On Asset, Return On Equity, Earning Per Share Corporate Value. The International Journal of Engineering and Science (IJES). ISSN, 2319-1813.

Saputri, R. E. (2019). Pengaruh Keputusan Investasi terhadap Nilai Perusahaan dengan Risiko Bisnis sebagai Variabel Intervening pada Perusahaan Manufaktur Di Bursa Efek Indonesia (BEI) Periode 2015-2017. Doctoral dissertation, Universitas Islam Negeri Raden Fatah.

Saraswathi, I. A. A., Wiksuana, I. G. B., \& Rahyuda, H. (2016). Pengaruh Risiko Bisnis, Pertumbuhan Perusahaan, dan Struktur Modal terhadap Profitabilitas serta Nilai Perusahaan Manufaktur. E-Jurnal Ekonomi dan Bisnis Universitas Udayana, 5(2016), 1729-1756.

Sartika, Y. D. (2017). Pengaruh Corporate Social Responsibility (CSR) terhadap Nilai Perusahaan yang Terdaftar Di Indeks Saham Syariah Indonesia (ISSI). Doctoral dissertation, IAIN Bengkulu.

Setiawan, D., Oemar. A., \& Pranaditya, A. (2017). Pengaruh Laba, Arus Kas, Likuiditas Perusahaan, Ukuran Perusahaan, Leverage, Kepemilikan Institusional, dan Kepemilikan Manajerial untuk Memprediksi Kondisi Financial Distress (Pada Perusahaan Manufaktur yang Terdapat di BEI Periode Tahun 2010-2015). Journal of Accounting, 3(3).

Sitinjak, S. S. (2020). Pengaruh Current Ratio dan Net Profit Margin terhadap Harga Saham di Perusahaan Bursa Efek Indonesia. Doctoral dissertation, Prodi Akuntansi.

Suartawan, I. G. N. P. A., \& Yasa, G. W. (2016). Pengaruh Investment Opportunity Set dan Free Cash Flow pada Kebijakan Dividen dan Nilai Perusahaan. Jurnal Ilmiah Akuntansi dan Bisnis, 11(2), 63-74.

Sudiani, N. K., \& Darmayanti, N. P. (2018). Pengaruh Profitabilitas, Likuiditas, Pertumbuhan, dan Investment Opportunity Set terhadap Nilai Perusahaan. E-Jurnal Manajemen, 5(7).

Tan, L. S. C. (2018). Analisa Likuiditas Saham dan Return Saham pada Perusahaan Tbk yang Terdaftar Di Bursa Efek Indonesia Sebelum dan Sesudah Stock Split.

Wardah, T. R. N. (2019). Pengaruh Good Corporate Governance, Leverage, Ukuran Perusahaan, dan Corporate Social Responsibility terhadap Nilai Perusahaan (Studi Empiris pada Sektor Industri Barang Konsumsi Di Bursa Efek Indonesia Periode 2014-2016). Doctoral dissertation, Universitas Muria Kudus.

Wiagustini, N. L. P., \& Pertamawati, N. P. (2015). Pengaruh Risiko Bisnis dan Ukuran Perusahaan pada Struktur Modal dan Nilai perusahaan pada Perusahaan Farmasi di Bursa Efek Indonesia. Matrik: Jurnal Manajemen, Strategi Bisnis dan Kewirausahaan.

Wijaya, R. A., \& Suganda, T. R. (2020). Pengaruh Investment Opportunity Set, Kinerja Keuangan, dan Intangible Asset terhadap Nilai Perusahaan. Akuntabel, 17(2) 215-225.

Yulia, Y., Arizona, N. D., \& Wong, V. (2020). Analisis Pengaruh Ekuitas Merek Pada Keputusan 
Pembelian Smartphone Iphone Xs Max di Indonesia. Jurnal Produktivitas: Jurnal Fakultas Ekonomi Universitas Muhammadiyah Pontianak, 7(1).

Yunita, S., \& Aji, T. S. (2018). Pengaruh Likuiditas, Tangibility, Growth Opportunity, Risiko Bisnis, dan Ukuran Perusahaan terhadap Struktur Modal Perusahaan (Studi Empiris pada Perusahaan yang Terdaftar dalam Development Board Sektor Infrastruktur, Ultilitas, dan Transportasi Periode 2012-2016). Jurnal Ilmu Manajemen (JIM), 6(4). 